The Evolution of the Theme of Sexual Difference as Revealed Through the Experience of Rape in Sibilla Aleramo's Una donna and Dacia Maraini's La lunga vita di Marianna Ucrìa

Catherine Ramsey-Portolano

\title{
OpenEdition
}

Journals

Electronic version

URL: http://journals.openedition.org/cei/928

DOI: $10.4000 /$ cei.928

ISSN: 2260-779X

Publisher

UGA Éditions/Université Grenoble Alpes

Printed version

Date of publication: 15 May 2008

Number of pages: $231-240$

ISBN: 978-2-84310-121-2

ISSN: 1770-9571

Electronic reference

Catherine Ramsey-Portolano, «The Evolution of the Theme of Sexual Difference as Revealed Through the Experience of Rape in Sibilla Aleramo's Una donna and Dacia Maraini's La lunga vita di Marianna Ucrìa ", Cahiers d'études italiennes [Online], 7 | 2008, Online since 15 November 2009, connection on 19 April 2019. URL : http://journals.openedition.org/cei/928 ; DOI : 10.4000/cei.928 


\section{THE EVOLUTION OF THE THEME OF SEXUAL DIFFERENCE AS REVEALED THROUGH THE EXPERIENCE OF RAPE IN SIBILLA ALERAMO'S UNA DONNA AND DACIA MARAINI'S LA LUNGA VITA DI MARIANNA UCRİA}

\section{Catherine Ramsey-Portolano}

Université américaine de Rome

In this article I will examine the evolution of the theme of sexual difference as revealed through the experience of rape in the novels of two Italian authors, Sibilla Aleramo's 1906 Una donna and Dacia Maraini's 1990 La lunga vita di Marianna Ucrìa. Aleramo's autobiographical novel and Maraini's fictional account of rape shed light on the historical reality of rape within the Italian context and immortalize its victims within the Italian literary canon. In both novels rape is utilized by the authors as a metaphor for the patriarchal violation of women. Aleramo and Maraini do not, however, limit themselves to portraying the patriarchal societies that have historically facilitated this violence against women, they challenge such societies by representing strong heroines who not only survive but triumph over their oppressor and the systems of oppression. Aleramo and Maraini recognize this violent historical reality and its patriarchal roots and respond to it by representing their protagonists' respective triumphs over their victimized female statuses.

In their respective novels Aleramo and Maraini explore similar ways in which women are able to find self-expression, through the written text and through sexuality. In such a way, both Aleramo and Maraini succeed in creating a symbolic female order in which their protagonists are able to express themselves, as opposed to the patriarchal order of contemporary society that does not appreciate their difference. However, while the theme of female sexuality is only briefly explored in Aleramo's early-20thcentury novel, in her late-20th-century text Maraini explores in full female sexuality as a means of freedom and self-expression for women. I

\footnotetext{
* Notes p. 240. 
will discuss Maraini's adherence to modern Italian feminist thought, which emphasizes the theme of sexual difference and the need for construction of a female alternative to traditional language and sexual practices based on the male model, as a key to understanding the evolution of sexual difference in Maraini's novel with respect to Aleramo's novel.

Aleramo observes in Una donna that men in early-20th-century Italian society are accustomed to thinking of woman as « un essere naturalmente sottomesso e servile ${ }^{1^{*}} »$. This perceived passivity of women is so embedded within the culture that when the protagonist's future husband reports to her that his friend is in love with her and wants to carry her off, she merely observes, "questo era un uso non raro in quei luoghi e al ratto seguiva il matrimonio" (27). Sharon Wood observes how Maraini's novel is also set in a time and place, that of 18 th-century Sicily, "where such an incident [as rape] would not even have been a punishable offence ", a society where "rape as a legitimate, non-criminalized act inscribed into the social order is the centrepiece of male oppression of women, of women's bodies ${ }^{2}$ ". Anna Camaiti Hostert notes that 18th-century Sicily was indeed «remarkable, even for that time, in the cruelty of its oppression of both the poor and women ${ }^{3} »$. It is within these repressive settings that Aleramo and Maraini's narratives of rape take place. Both novels trace the lives of their respective protagonists from their innocence in childhood through their traumatic experiences of rape and the resulting loss of innocence.

Before her experience of rape, Aleramo's protagonist is a confident and carefree individual who asserts that "non mi sarei mai maritata, che non sarei stata felice se non continuando la mia vita di lavoro libero, e che, del resto, tutte le ragazze avrebbero dovuto far come me... Il matrimonio... era un'istituzione sbagliata" (28). Shortly after she makes this statement however, she laments, "D'improvviso la mia esistenza [...] veniva sconvolta, tragicamente mutata. Che cos'ero io ora? Che cosa stavo per diventare? La mia vita di fanciulla era finita?» (35). What has occurred is her rape, at age fifteen, by a fellow employee at her father's factory. The protagonist provides a confused account of the event, stating,

Così, sorridendo puerilmente, accanto allo stipite di una porta che divideva lo studio del babbo dall'ufficio comune, un mattino fui sorpresa da un abbraccio insolito, brutale, due mani tremanti frugavano le mie vesti, arrovesciavano il mio corpo fin quasi a coricarlo attraverso uno sgabello, mentre istintivamente si divincolava. Soffocavo e diedi un gemito ch'era per finire in urlo, quando l'uomo, premendomi la bocca, mi respinse lontano. (34) 
Although the young protagonist does not fully understand what has happened to her, she is aware that its consequences will affect her entire life. As was common in the protagonist's society, the rape victim will later marry her rapist. She later reflects, "accettando l'unione con un essere che m'aveva oppressa e gettata a terra, piccola e senza difesa, avevo creduto di ubbidire alla natura, al mio destino di donna che m'imponesse di riconoscere la mia impotenza a camminar sola» (82). The protagonist thus loses her independence along with her virginity as a result of this violent sexual act.

Marianna Ucrìa, the protagonist of Maraini's novel, also loses her virginity in a childhood experience of rape and is forced by her family to later marry her rapist, although neither she nor the reader becomes aware of these facts until Marianna is an adult, due to her repression of the traumatic event. Maraini reports the events leading up to Marianna's rape retrospectively, revealing the secret origins of Marianna's loss of hearing and speech through the recollections of her older brother Carlo,

Cosa cavolo stava succedendo in quei labirinti di via Alloro ? una sera si erano sentiti dei gridi da accapponare la pelle e Marianna con le gambe sporche di sangue era stata portata via, sì trascinata dal padre e da Raffaele Cuffa, strana l'assenza delle donne... il fatto è che sì, ora lo ricorda, lo zio Pietro, quel capraro maledetto, l'aveva assalita e lasciata mezza morta... [...] per amore diceva lui, per amore sacrosanto che lui l'adorava quella bambina e se n'era 'nisciutu pazzu'4 .

As a result of this traumatic experience, Marianna, once a healthy child, loses two of her senses and is relegated to the fringes of a society that looks down upon those with disabilities.

Both Aleramo and Maraini portray the lasting effects of the rapes that their protagonists experienced as children as well as the marital rapes that they experience as adults. Because of their brutal sexual initiations, neither protagonist is able to enjoy her later sexual encounters. However, they are continually violated by the same men who initially violated them as children, despite their protests and attempts to escape.

As a young bride, Aleramo's protagonist notes that «il mio distacco dal mondo, ora, era sincero; dotata di gioventù e di bellezza, io potevo, mercé la crisi attraversata, credermi esente per sempre da ogni desiderio dei sensi» (119). However, she is not immune to her husband's sexual desires and advances, to which she is forced to submit against her wishes. After years of forced sexual encounters, the protagonist laments, "Questa la mia vita. Essere adoprata come una cosa di piacere, sentir avvilita l'intima mia sostanza. E vedere i giorni seguir le notti, un dopo l'altro, senza fine» 
(189). Aleramo's protagonist finds only debasement in her relationship with the man who initiated her to sexuality.

Like Aleramo's protagonist, Marianna will also reflect after years of non-consensual sexual encounters,

può una donna di quarant'anni, madre e nonna, svegliarsi come una rosa ritardataria da un letargo durato decenni per pretendere la sua parte di miele ? che cosa glielo proibisce ? niente altro che la sua volontà ? o forse anche l'esperienza di una violazione ripetuta tante volte da rendere sordo e muto tutto intero il suo corpo ? (190)

Wood notes regarding La lunga vita di Marianna Ucria that «images and rhetorical devices underline the connection between physical violence and sexuality» (233). Indeed, Marianna's description of her sexual encounters with her husband provide the reader with powerful and violent imagery of marital rape. She describes her husband's embrace as "quell'abbraccio da lupo» and sexual relations with him as "una corsa senza scampo" (89). His hands are "le zampe del predatore sul collo» (89) and his body is « un corpo che non le ha mai ispirato amore per quei modi austeri, violenti e freddi a cui si accompagnava» (149). Sex with her husband is, indeed, not only empty but violent and degrading for Marianna. Resulting from the initial and subsequent brutal encounters with her husband, Marianna is unable to derive any pleasure from the act.

Maraini and Aleramo both vividly depict the negative consequences of rape on their protagonists, yet they respond to this patriarchallycondoned violence against women by allowing their protagonists to ultimately overcome their victimized status. Aleramo's protagonist reaches the turning point in her life when she attempts and survives suicide. Upon reaching the lowest point of her life, she is able to localize the moment of descent in her rape by her future husband, «Da quanto tempo la crisi si svolgeva in me a mia insaputa? Il dì in cui un informe essere aveva brutalmente interrotto la fioritura della mia adolescenza, un processo di dissolvimento s'era iniziato in me» (91). The protagonist's suicide attempt represents, therefore, the attempt to end the life of the woman she had been until that point, a woman with no form of self-expression, trapped in an abusive relationship.

The protagonist's survival is proof that death is not the only escape for a woman in her situation. Her road to freedom, however, is not an easy one and she is forced to make sacrifices in order to achieve it. When she reflects on the life of her mother, she exclaims, "Amare e sacrificarsi e soccombere ! Questo il destino suo e forse di tutte le donne ?» (55). Una donna's protagonist decides, however, that such will not be her ultimate destiny. Her first act of rebellion against her repressive surroundings is the 
act of reading. It is through reading that the protagonist is able to escape to some extent her isolated existence, often confined to one room of her house during the day, and feel herself connected to the outside world: "Mercé i libri io non ero più sola, ero un essere che intendeva ed assentiva e collaborava ad uno sforzo collettivo" (110). Aleramo's protagonist also resists the isolated existence and restrictions imposed upon her by contemporary society through the act of writing. Beginning with a diary of reflections on her experiences and those of her growing son, she progresses to writing articles for women's journals, writing on topics from social to feminist issues. Her collaboration with a journal will offer the first chance for liberation from her suffocating existence in the small town in which she lives when she moves to Rome for a brief period to work for the journal.

The protagonist of Una donna also rebels against the patriarchal culture that views a wife's body as the property of her husband to use and violate at his discretion. Although she suffers his unwanted sexual advances for many years, she is eventually able to stand up to him, refusing to have sexual relations with him after he is diagnosed with a sexually-transmitted disease. Not only is the protagonist finally able to reject the man who has violated her repeatedly, but she further triumphs over her experience of rape by reclaiming her own sexuality. Now no longer the young girl who passively submitted to the social practice of marrying the man who raped her, she comes to challenge the patriarchal ideas of women as objects rather than subjects who are able to enjoy their own sexual experiences. When she first awakens to this idea, she relates, «E i miei vent'anni insorsero... Perché non avrei potuto esser felice un istante, perché non avrei dovuto incontrare l'amore, un amore più forte di ogni dovere, di ogni volere? Tutto il mio essere lo chiamava» (83) She blames the patriarchal society, which allows her husband to hold her captive, for her repression but she is determined not to allow it to conquer her, as her thoughts reveal,

sentivo nel mio sangue penetrare la persuasione d'un diritto mai soddisfatto, e con essa un impeto formidabile di conquista, lo spasimo di raggiungere, di conoscere quella gioia dei sensi che fa nobile e bella la materia umana ; quella fusione di due corpi in un sospiro di felicità dal quale il nuovo essere prenda l'impulso alla vita trionfante? (188)

Aleramo's protagonist does not, however, find the sexual satisfaction she feels is lacking in her life. Aleramo stops short of representing this form of self-realization and expression for her protagonist, leaving merely the suggestion of its possibility. The protagonist's ultimate act of rebellion 
consists instead in fleeing the man and the society that have oppressed her. Encouraged by her older female friend in Rome who declares to her : "Sai pure che la rassegnazione non è una virtù !» (183), she first attempts to break free from her relationship with her husband by remaining in Rome, rather than moving back to his hometown. Although the attempt does not succeed, a year later she states, "Ma adesso, dopo l'annata di tormentosa e inflessibile meditazione, dopo la visione raccapricciante dell'abisso, era un commando cui dovevo obbedire, o morire» (210). Despite the patriarchal laws that deprive her of her right to her son or to her own money, she cannot be dissuaded from this decision. Although she mourns the loss of her son, one day several months after her departure she realizes " con uno strano stupore che vivevo ancora, che nulla di essenziale era veramente morto in me, e che d'ogni intorno, quasi occultamente, mille enigmi mi sollecitavano» (218). By the end of the novel, she has triumphed over the traumatic sexual violation of her childhood and the repeated partriarchally-sanctioned violations experienced throughout her adult life.

Through the relationship that develops between Una donna's protagonist and her older female friend, Aleramo suggests a relationship of entrustment between women, anticipating modern Italian feminist thought on the benefits for women of a female order. Thinkers in the Libreria delle Donne di Milano and the Veronese feminist philosophical group Diotima have explored a feminist alternative to the sexist structures of patriarchal society by rejecting the Freudian interpretation of familial relations and re-examining the mother-daughter relationship as a way of recuperating the mother as a positive figure within familial and social structures. The 1987 Libreria delle Donne di Milano volume Non credere di avere dei diritti proposes a female order that exalts woman's qualities and capabilities in contrast to the existing male order, which negates those qualities and capabilities. The notion of affidamento between women, in the recognition of what women have to offer each other, is suggested as a way of establishing a female order : "Affidarsi a una propria simile spesso, se non sempre, è indispensabile a una donna per raggiungere un fine sociale $»$. Rebecca West refers to relationships of affidamento as "processes of mediation whereby more experienced and more authoritative women provide female modes of access to the world and to effective agency for their less experienced and usually younger 'affidate,' thus seeking to nullify the more deleterious effects of patriarchal power-based modes of mediation which do not take into account sexual difference ${ }^{6}$. In her early-20th-century novel, Aleramo creates a positive female model 
for her female protagonist and suggests a possible female order for women of her time, thereby anticipating modern Italian feminist theory.

Maraini also allows her protagonist to triumph over the violence she has suffered at the hands of patriarchal society, represented in Marianna's case by her own family. In fact, when her brother Carlo recalls Marianna's rape, he refers to it as "un segreto di famiglia," "un affare fra uomini" (210). It is precisely the father's role in covering up the episode of Marianna's rape that perhaps most wounds her, as the following passage reveals, "Mai avrebbe immaginato che il signor padre e il signor marito zio tenessero in comune un segreto che la riguardava; che si fossero alleati tacendo a tutti di quella ferita inferta al suo corpo di bambina" (245). The moral wound of her father's compliance in the act is far more hurtful than the physical wound of the rape itself, as Joann Cannon observes, «At the origin of Marianna's malady lies not only a traumatic event, but, more important, the very structure of patriarchal society in which women are exchanged in accordance with the law of the father ${ }^{7}$ ». Although Marianna has been betrayed by the men in her family and subjected to violence because of her role as a woman in a patriarchal society, the novel traces her triumph rather than her defeat. Although recognizing that Marianna is scarred by the violence that she has undergone at the hands of patriarchal society, Cannon suggests that

Unlike the "fallen» heroines of the male-authored, feminocentric novels, Marianna will not succumb to her fate. In such works as Clarissa, rape marks the end of the heroine's story, the point at which the heroine's fate has been sealed. In Maraini's novel, by contrast, the rekindled memory of the rape ultimately opens up now possibilities to the protagonist. Freed from obedience to a father who betrayed her and a husband who abused her, Marianna's lunga vita has only begun. (144).

In contrast to Aleramo's novel, where the experience of rape is a painful experience to be forgotten and overcome, in Maraini's novel the protagonist's realization of her rape as a young child is the catalyst for her selfliberation from the oppressions of the society that has thus far violated and restricted her. In fact, shortly after coming to know of her rape, Marianna has the courage to discover sexual passion for the first time with the young servant Saro.

As in Una donna, reading and writing become two ways in which Marianna succeeds in rebelling against the patriarchal society that rejects her because of her difference as deaf and oppresses her because of her status as woman. Because the men in her family have damaged Marianna through the violent act of rape, her desire to read and write, activities not common for women of the time, is excused. Cannon, in fact, notes that 
Marianna's muteness «becomes not only a sign of female subjugation but also a means to challenge the female destiny as written by patriarchy. Marianna's muteness encourages and excuses one of her most subversive activities - her predilection for reading» (141). Marianna thus receives an exceptional education, even for women of the upper class, which allows her to express herself in ways that are uncommon for the time. It is through reading, for example, that Marianna discovers and interrogates herself on the writings of English philosopher David Hume. Yet Marianna's handicap and intellectual capabilities qualify her as "other» in the eyes of contemporary society, as the following passage reveals,

Di lei, mutola, i campieri e i gabelloti hanno una soggezione che rasenta la paura. La considerano una specie di santa, una che non appartiene alla razza grandiosa dei signori ma a quella miserabile e in qualche modo sacra degli storpi, dei malati, dei mutilati. Ne hanno pietà ma sono anche irritati dai suoi occhi curiosi e penetranti. E poi non sanno scrivere e lei con i suoi biglietti, le sue penne, le mani macchiate d'inchiostro li mette in uno stato di agitazione insopportabile. (155)

Reading and writing constitute an alternative path for Marianna to language and the role within society from which she is excluded. Unable, or unwilling, to make her voice heard, Marianna finds an autonomous space in which to make her words heard: the space of writing.

Camaiti Hostert writes that La lunga vita di Marianna Ucrìa "describes a transition from a patriarchal world where women are silenced to a female symbolic order in which women are finally able to speak their own language» (286). The notion explored by Maraini of women's silencing within patriarchal society and the need for an alternative means of expression for women recalls contemporary Italian feminist theory on sexual difference. In the 1987 Diotima volume Il pensiero della differenza sessuale, Adriana Cavarero emphasizes woman's need for a language that breaks away from the language of patriarchal society, which is based on the male model and is therefore a «foreign» language for women. Cavarero notes the following possible alternatives for women : «In questa esperienza di distanza della lingua, trovano spazio vie di fuga a noi ben note : il silenzio, il residuo non detto, il corpo piuttosto che il pensiero ${ }^{8} »$. In her novel Maraini explores such escape routes for the protagonist of her novel : first through silence, then through writing and finally through rediscovery of her body and her sexuality.

Marianna rebels against the expectations of patriarchal society and finds self-expression by eventually refusing to give her body to the man who raped her as a child and who has forced sexual relations upon her throughout their marriage. After the birth of their fifth child, "per la 
prima volta, guardando in faccia il signor marito zio, [Marianna] riesce a fare un segno di diniego con la testa» (90). Not long after she decides to cease sexual relations with her husband, Marianna's body awakens to the possibility of sexual pleasure when she discovers passion with Saro. However, the relationship with Saro reveals not only the possibility and existence of sexual pleasure to Marianna, as the description of Marianna and Saro's first sexual encounter reveals, «Sa che si sono abbracciati come due corpi amici e accoglierlo dentro di sé è stato come ritrovare una parte del proprio corpo che credeva perduta per sempre» (238). In contrast to the violence of the patriarchal sexual encounters experienced with uncle husband, with Saro Marianna discovers the existence of a mutual relationship in which she as woman is also able to express her sexuality. Wood notes that "Maraini emphasizes in this novel that real freedom for the woman lies in the re-appropriation of the expressivity of her own body. For Maraini it is not the text, the word, but the body which is the primary expression of female identity and self" (226). At the end of the novel, Marianna regains power over her violated body and learns to communicate sexual desire and passionate love.

It is this aspect of Marianna's victory, the rediscovery and acceptance of her body and its sexuality, that constitutes the principal form of evolution of the theme of sexual difference in Maraini's novel with respect to Aleramo's novel. It is also through this victory for Marianna that Maraini further adheres to contemporary Italian feminist thought on sexual difference. In the 1983 Libreria delle Donne di Milano article «Più donne che uomini," the authors discuss woman's blocked potentiality within patriarchal society:

Nello scacco come nel disagio diffuso si avverte che la cosa che fa ostacolo, che non c'entra con i giochi sociali, è in definitiva il fatto di essere e avere un corpo di donna. [...] Lo scacco si produce perché l'essere donna, con la sua esperienza e i suoi desideri, non ha luogo in questa società, modellata dal desiderio maschile e dall'essere corpo di uomo?.

The authors locate woman's sense of discomfort and inadequacy within patriarchal society precisely in the female body. In a society dominated by male ambition and desire, the expression of woman's profound feelings and desires and of an intelligence true to her emotions and desire are not allowed free rein and therefore become distorted or are silenced. In La lunga vita di Marianna Ucrì Maraini explores the ways in which woman can uncover and freely express her desires through the protagonist's discovery of the pleasures of her body and sexuality. At the end of the novel, Marianna's body is no longer an obstacle or a object of male 
pleasure but rather a vehicle for the attainment of self-satisfaction and fulfilment.

In the conclusion of Maraini's novel the protagonist enacts, as the protagonist of Una donna had also done, a final rebellion against the patriarchal forces put into play by her family and by society when she "defies the conventional moral restrictions of class and gender roles ${ }^{10}$ " by leaving her home and family and starting a new life. The protagonists of La lunga vita di Marianna Ucria and Una Donna defy the conventions of contemporary Italian society that restrict women's freedom, thereby rejecting the society that has harmed them in the past. Cannon observes regarding Maraini's novel how such an ending "inscribes a new female destiny, a new ending to the female Bildungsroman. That ending suggests that for Marianna, and for heroines to come, the female journey is an open-ended one" (146).

\section{Notes}

1. S. Aleramo, Una donna, Milano, Feltrinelli, 1997, p. 30. All citations from Una donna refer to this text.

2. Sh. Wood, "The Language of the Body and Dacia Maraini’s Marianna Ucrìa. », Journal of Gender Studies 2.2, November 1993, p. 223-237.

3. A. Camaiti Hostert, "Afterword", The Silent Duchess, Dacia Maraini, Trans. D. Kitto \& E. Spottiswood. New York, The Feminist Press at the City University of New York, 1998, p. 250.

4. D. Maraini, La lunga vita di Marianna Ucrìa, Milano, Rizzoli, 1990, p. 209-210. All citations from La lunga vita di Marianna Ucrìa refer to this text.

5. Libreria delle Donne di Milano, Non credere di avere dei diritti., Torino, Rosenberg \& Sellier, 1987, p. 18.

6. R. West, "Women in Italian," in Italian Studies in North America. Eds. M. Ciavolella \& A.A. Iannucci. Ottawa, Dovehouse, 1994, p. 210.

7. J. Cannon, «Rewriting the Female Destiny : Dacia Maraini’s La lunga vita di Marianna Ucria ", Symposium 49.2, Summer 1995, p. 136-146.

8. A. Cavarero, «Per una teoria della differenza sessuale, » in Diotima, Il pensiero della differenza sessuale, Milano, La Tartaruga, 1987, p. 53.

9. Libreria delle donne di Milano, «Più donne che uomini.» Sottosopra, January 1983.

10. Sh. Wood, "The Language of the Body and Dacia Maraini's Marianna Ucrìa ", Journal of Gender Studies 2.2, November 1993, p. 225. 